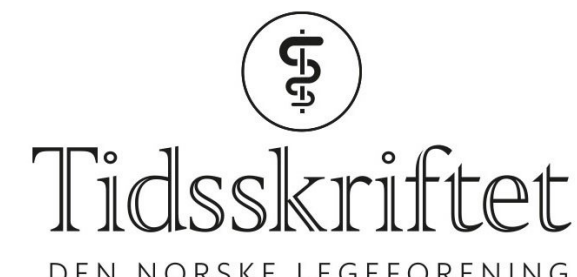

DEN NORSKE LEGEFORENING

\title{
Demokratiet dør i skyggene
}

FRA REDAKTØREN

KETIL SLAGSTAD

E-post: ketil.slagstad@tidsskriftet.no

Ketil Slagstad er lege og medisinsk redaktør i Tidsskriftet.

Et sunt samfunn kjennetegnes av en sterk offentlighetskultur. Som leger har vi ansvar også for samfunnskroppens helse.

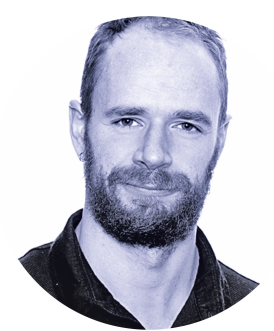

Foto: Sturlason

Medisin er politikk. Per Fugelli skrev: «Helse er lik biologi x kultur x politikk opphøyd i andre potens» (1, s. 14). Politikkutforming er ikke forbeholdt stortingssalen, men foregår i stor grad i offentligheten. Det norske sosialdemokratiske samfunn, som er kjennetegnet av relativt egalitære forhold og stor grad av tillit mellom befolkningen og de styrende, ble til som følge av en vilje til sterk statlig styring - men også av en bred offentlighetskultur (2).

Medisin er makt. Helsevesenet følger oss fra vugge til grav, og hvordan vi forstår våre kropper og oss selv, er i stor grad definert av moderne medisin (3). Vi leger har derfor stor makt i kraft av vår kunnskap og posisjon. Medisinsk kunnskap kommer samfunnet til gode. Samtidig er det et demokratisk problem når politikere i helsefaglige spørsmål abdiserer til fordel for ekspertokratiet: Politikken er utformet før den har blitt debattert offentlig og i stortingssalen (4). Da konsentreres den medisinske ekspertmakten ytterligere. Makt bør møtes med motmakt, i dette tilfellet en bred og opplyst offentlighet. Men med økende subsubspesialisering og fragmentering av legerollen er det lett at vi leger melder oss ut av den offentlige debatten så snart det er andre temaer enn dem som berører vår lille nisje. I tillegg bærer vi med oss en autoritær og patriarkalsk medisinsk tradisjon som ikke har dyrket tvil og offentlig argumentasjon (5).

Kan det være at vi som leger ikke i tilstrekkelig grad opplæres i offentlig debatt og ikke er bevisst dens demokratiserende funksjon? Som medisinstudent for et tiår siden var min opplevelse at kritisk drøfting, argumentasjon og legers folkeopplysende ansvar var fraværende fra læreplanen. Å lage læreplaner i et fag der kunnskapstilfanget er så eksplosivt som i medisinen, kan ikke være en takknemlig oppgave. Om noe skal tas inn, må noe annet tas ut. En e-post til landets studiedekaner ved de medisinske fakultetene viser at ingen av lærestedene tilbyr spesifikk undervisning i offentlig debatt eller konkret skriveopplæring. I 
Oslo tilbys en egen undervisningsseksjon i helsepolitikk der studentene øver seg på å fremføre ulike synspunkter i helsedebatten, og i Troms $\emptyset$ er det et eget kurs i vitenskapelig kommunikasjon. Det er bra, men argumentasjon må læres og å lære å skrive fordrer trening. Deltagelse i offentlig debatt bør ikke forbeholdes den enkelte engasjerte lege, snarere bør det være en del av den dannelsesoppgaven de medisinske fakultetene står ansvarlig for.

Mitt forslag er å gi studentene helt konkrete skriveoppgaver, for eksempel å skrive en folkeopplysende tekst om mensen eller hvorfor PSA-testen ikke bør brukes ureflektert, eller å skrive et debattinnlegg om hvordan private digitale helsetjenester vil supplere eller undergrave det offentlige helsevesenet. Offentlig meningsbrytning innebærer å møte ens meningsmotstander med argumenter, «ansikt til ansikt», uten å konstruere stråmenn, men ved å referansebelegge påstander. Det handler om å dyrke polemikk og spissformuleringer (6). Få debatter oppstår i et konsensussøkende og konfliktvegrende klima.

Tidsskriftet satte for noen år siden Brev til redaktøren først i papirutgaven som et signal om at vi ønsket å prioritere debattstoffet (6). Seksjonen har siden endret navn til Kommentarer, for å understreke at det ikke er oss redaktører du som leser skriver for, men norske leger og norsk offentlighet. Vi prioriterer kommentarene og publiserer dem fortløpende på vår nettside. Som redaksjon har vi vært opptatt av ikke bare å være postkasse, men også aktivt invitere inn skribenter som kan målbære maktkritiske perspektiver som tradisjonelt ikke har blitt hørt i medisinen, for eksempel tidligere psykiatriske pasienter (7) og aktivister (8). Lenge var norsk medisin forbeholdt hvite menn. Slik er det heldigvis ikke lenger; i 2018 ble $44 \%$ av debattartiklene skrevet av kvinner. Vi vil være et tidsskrift for alle norske leger og medisinstudenter. I likhet med andre medisinske tidsskrifter (9) har vi satt oss som mål i større grad å speile mangfoldet i medisinen og blant forfattere, for eksempel med hensyn til ulike kjønn, bosted, etnisitet og hvor man er i karrieren. Med det anerkjenner vi at det også er medisinske tidsskrifters oppgave å jobbe mot strukturelle rasistiske og diskriminerende mekanismer i medisinen.

Norske leger gir norsk offentlighet en gave ved å sikre fri tilgang til Tidsskriftet gjennom medlemskontingenten. Vitenskapen avhenger av fri debatt, det samme gjør demokratiet. "Democracy Dies in Darkness», er mottoet til The Washington Post. Jobben med å sikre en bred demokratisk offentlighet må vi gjøre på dugnad - sammen.

\footnotetext{
LITTERATUR:

1. Fugelli P. Rød resept. Essays om perfeksjon, prestasjon og helse. Oslo: Tano Aschehoug, 1999.

2. Slagstad R. De nasjonale strateger. Oslo: Pax forlag, 1998.

3. Cooter R, Pickstone J. red. Companion to medicine in the twentieth century. London: Routledge, 2003 .

4. Slagstad R. Den nye helseadelen. Tidsskr Nor Legeforen 2017; 137. doi:10.4045/tidsskr.17.0400. [PubMed][CrossRef]

5. Hem E. Medisin er debatt. Tidsskr Nor Legeforen 2012; 132: 1941. [PubMed][CrossRef]

6. Lie AK. La oss diskutere. Tidsskr Nor Legeforen 2010; 130: 471. [PubMed][CrossRef]

7. Nesset M, Teien AG. Reservasjonsrett i psykiatrien nå! Tidsskr Nor Legeforen 2017; 137. doi: 10.4045/tidsskr.17.0494. [PubMed][CrossRef]

8. Lekanger A. Kriminalisering av sexarbeid gir mer hivsmitte. Tidsskr Nor Legeforen 2017; 137: 516-7. [PubMed][CrossRef]

9. Clark J, Horton R. What is The Lancet doing about gender and diversity? Lancet 2019;393: 508-10. [PubMed][CrossRef]
} 
(ㅇ) Tidsskrift for Den norske legeforening 2020. Lastet ned fra tidsskriftet.no 